\title{
Environmental Policy Design and the Fragmentation of International Markets for Innovation
}

\author{
NiCK JOHNSTONE \\ IVAN HASCIC
}

\begin{abstract}
CESIFO WORKING PAPER NO. 2630
CATEGORY 9: RESOURCE AND ENVIRONMENT ECONOMICS
\end{abstract}

APRIL 2009

Presented At CESifo Venice Summer Institute, July 2008

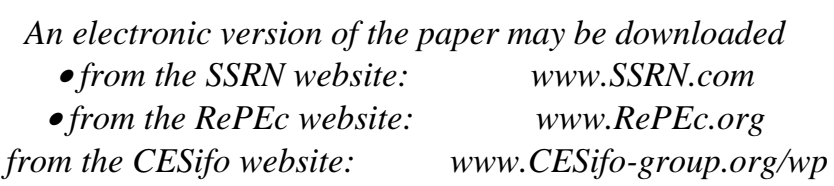




\title{
Environmental Policy Design and the Fragmentation of International Markets for Innovation
}

\begin{abstract}
It has long been argued that the implementation of market-based environmental policy instruments such as environmentally-related taxes and tradable permits is likely to lead to greater technological innovation than more direct forms of regulation such as technologybased standards. One of the principle reasons for such an assertion is that they give firms greater „flexibility" to identify the optimal means of innovating to meet the given environmental objective. Thus, it can be argued that the benefits of (some) market-based instruments can also be true of well-designed performance standards. While the theoretical case for the use of flexible policy instruments is well-developed, empirical evidence remains limited. Drawing upon a database of patent applications from a cross-section of countries evidence is provided for the positive effect of "flexibility" of the domestic environmental policy regime on the propensity for the inventions induced to be diffused widely in the world economy. For a given level of policy stringency, countries with more flexible environmental policies are more likely to generate innovations which are diffused widely and are more likely to benefit from innovations generated elsewhere. And while the focus of this paper is on the specific case of environmental policy, the discussion is equally applicable to aspects of product and labour market regulation which have implications for technological innovation, such as product and workplace safety.
\end{abstract}

JEL Code: Q55, Q56, Q58, O31, O33, O38.

Keywords: environmental policy, market fragmentation, innovation, technology transfer.

Nick Johnstone

Empirical Policy Analysis Unit

OECD Environment Directorate

Nick.Johnstone@oecd.org
Ivan Hascic

Empirical Policy Analysis Unit

OECD Environment Directorate

Ivan.Hascic@oecd.org

This version March 30th, 2009

The authors would like to thank Andreas Loeschel and other participants for comments received at the CESIFO Summer Institute on "Reforming Rules and Regulations", where this work was initially presented. The views expressed here are authors' own and do not necessarily reflect those of the OECD or its member countries. 


\section{ENVIRONMENTAL POLICY DESIGN AND THE FRAGMENTATION OF INTERNATIONAL MARKETS FOR INNOVATION}

\section{Introduction}

It has long been argued that the implementation of market-based environmental policy instruments such as taxes and tradable permits is likely to lead to greater technological innovation than more direct forms of regulation such as technology-based standards, since they give firms the 'flexibility' to identify the optimal means of innovating to meet the given environmental objective. ${ }^{2}$ While the theoretical case for the use of market-based instruments is well-developed, ${ }^{3}$ empirical evidence remains limited. ${ }^{4}$

This paper seeks to contribute to the body of evidence which relates to this proposition. In particular, it is argued that the more flexible is an individual country's environmental policy regime the more likely it is to induce innovations which are able to find markets overseas. The reason for this is intuitive. If more 'prescriptive' policies such as technology-based standards are applied, the technology adoption decision is constrained by the precise characteristics of the standard. And unless other countries adopt standards which are equivalent in nature, the innovations induced are unlikely to be acceptable to permitting authorities overseas. This has the potential to fragment markets for innovation along national (or even sub-national) lines. Conversely, more 'flexible' market-based instruments are likely to induce innovations which are potentially applicable in a wider variety of policy settings. This reduces commercial uncertainty associated with research and development, and may allow for the realisation of economies of scale.

\footnotetext{
${ }^{2}$ Assuming that the point of incidence of the tax or permit relates directly to the externality to be mitigated.

${ }^{3}$ See Downing and White (1986), Milliman and Prince (1989), Nentjes and Wiersma (1987) and, Jung et al. (1996).

${ }^{4}$ Jaffe, Newell and Stavins (2002) and Vollebergh (2007) both provide recent reviews of the empirical literature on this theme.
} 
Drawing upon a database of patent applications from a cross-section of countries evidence is provided for the positive effect of 'flexibility' of the domestic environmental policy regime on the propensity for the inventions induced to be diffused widely in the world economy. A measure of international technology transfer is developed for technologies which relate to the mitigation of air and water pollution and solid waste management. The results of the empirical analysis confirm the positive role of policy flexibility on international technology transfer.

Following this introduction, section 2 provides a discussion of the potential role of regulation in fragmenting markets for innovation. Section 3 describes the data used to measure both technology transfer and policy flexibility. Section 4 provides a description of the empirical model, as well as the results. The paper concludes with a brief discussion of policy implications.

\section{Environmental Regulation and Fragmentation of Innovation Markets}

While the empirical evidence on the effects of environmental policy on trade in goods and services remains limited and ambiguous, ${ }^{5}$ there is reason to expect that differences in environmental policy regimes would have an effect on international trade and foreign direct investment patterns. While some environmentalists have argued that policies should be harmonised in order to avoid such effects, this is unlikely to be welfare-improving. Environmental policies may differ across countries due to both supply (i.e. ecological conditions) and demand conditions (i.e. preferences for environmental quality), and these factors should be reflected in domestic policy regimes if it is to bring about welfare improvements. While there are some arguments for policy harmonisation in certain cases (e.g. imperfect enforcement, transfrontier pollution), economists are more concerned with the potential for domestic environmental policy to be used as a barrier to trade in order to protect domestic industries (see Ederington and Minier 2003 for a recent empirical study). ${ }^{6}$

\footnotetext{
${ }^{5}$ See Levinson and Taylor (2008) which provides new results and a methodological discussion of the reasons why positive evidence in this area remains limited.

${ }^{6}$ See Greaker and Eggert (2008) for a discussion of the GMO case.
} 
Unfortunately much of the relevant literature in this area has focused on the effects of differences in the stringency of environmental policy, and not on the effects of differences in policy design. However, it is well-known that different policy instruments will affect the incentives for firms to develop and adopt environmentally beneficial technologies in different ways. In general, a strong case has been made for the use of market-based instruments (e.g. taxes, tradable permits), rather than direct regulation (e.g. technology-based controls, performance standards) in order to induce innovation (see Jaffe et al. 2002 for a review). In particular, it is argued that the rate of innovation under market-based instruments is more likely to be optimal since a greater proportion of benefits of technological innovation and adoption will be realised by the firm itself than is the case for many direct forms of regulation. Moreover, since market-based instruments are not 'prescriptive', they are more likely than many types of direct regulation to ensure that the direction of technological change is cost-minimising with respect to the avoidance of damages. ${ }^{7}$

However, the stark juxtaposition between market-based instruments and direct forms of regulation is somewhat misleading. Rather it is more helpful to think in terms of vectors of characteristics of different instruments, and what effect each of these characteristics has on innovation. Relevant vectors would include at least the following:

- Flexibility - i.e. does it let the innovator figure out the best way to meet the objective (whatever that objective may be)

- $\quad$ Targeted - i.e. is the point of incidence of the policy directly on the externality or is it on a 'proxy' for the pollutant

- Depth-i.e. are there incentives to innovate throughout the range of potential objectives (down to zero emissions)

\footnotetext{
${ }^{7}$ See Jaffe et al. (2002).
} 
- Stability - i.e. does the policy measure provide a signal to pontential inventors which contributes to (or reduces) investor uncertainty

There is no precise mapping from instrument type to each of these. For instance, different environment-related taxes may have very different attributes. A tax on $\mathrm{CO}_{2}$ is flexible, targeted, deep, and often predictable. However, a differentiated tax for 'environmentally friendly products' is not flexible, targeted or deep. ${ }^{8}$ Indeed it could be argued that such a measure would have more similarity with technology-based standards than with a $\mathrm{CO}_{2}$ tax. More generally, a performance standard with a similar point of incidence (i.e. on the pollutant itself) and degree of flexibility may have more similarities with a tax than with a technology-based standard.

In addition to their effects on the rate of innovation, different policy measures (of equal stringency) are likely to generate different types of innovation. As such, if different countries introduce different types of policy measure, there is likely to be national specialisation in different types of technological innovation to meet similar environmental objectives. This fragmentation of environment-related innovation along national lines can result in increased costs in meeting given environmental objectives. While the effects of policy design on the international diffusion of innovations has not been addressed in the literature, in other areas there is evidence of the costs associated with differentiated regulatory systems for pharmaceutical (Vogel 1998) and food (Thilmany and Barrett 1999) markets. In the environmental domain, there have been a number of studies on the effect of differentiated gasoline content regulations in the United States on gasoline price levels and variability (see Morris and Stewart 2007, Chakravorty and Nauges 2005, and Chakravorty et al 2007).

In addition to the price effects of policy heterogeneity, the potential innovation effects of this regulatory heterogeneity may be considerable. Since investment in $R \& D$ is risky, any measures which constrain the potential market for innovations generated are likely to present a significant

\footnotetext{
${ }^{8}$ For instance, the application of the "bonus-malus" system on the sales price of motor vehicles in France.
} 
disincentive. Moreover, it can be costly to gather the information required in order to determine what types of innovations are likely to be permitted under a wide variety of policy regimes. However, no empirical evidence on the innovation impacts of policy design is available. Moreover, the specific effect of the 'flexibility' of domestic environmental policy has not been addressed. Since flexible environmental policies - whether they be environment-related taxes, tradable permit systems, or even non-prescriptive performance standards - allow for the use of a wide variety of technological measures, international market applications are likely to be wider. It might be imagined that such effects could also be realised through the implementation of identical technology-based standards. Indeed this is similar to the arguments put forth by Sykes (1995) and others. ${ }^{9}$ However, this assumes a level of coordination which is unlikely to be realised in practice for environmental technologies, although Coninck et al. (2008) provide some examples of international technology-oriented agreements related to climate change.

Alternatively, in circumstances where a dominant country regulates first, the policy may induce innovations which affect the policy decisions of subsequent regulators, encouraging them to adopt similar regulations. The example of California motor vehicle emissions controls might represent such a case. ${ }^{10}$ While this may result in an unfragmented market, it does so at the cost of imposing regulations of equal stringency across countries with different ecological conditions and heterogeneous demand for environmental quality. There is no reason to expect that the optimal path of innovation will be induced. Conversely, the use of flexible instruments allows for broad markets for innovation, as well as differentiated levels of stringency. In effect, with flexible instruments the level of stringency determines the size of different national markets, without bringing about market fragmentation.

\footnotetext{
${ }^{9}$ Standardisation is, of course, important in the presence of network externalities (see Shy 2001). However, this is of limited relevance to environmental concerns.

${ }^{10}$ See Vogel (1995). However, an empirical study by Fredriksson and Milliment (2002) finds limited evidence of the 'California effect' in state-level environmental policymaking.
} 


\section{Data construction and interpretation}

As noted above, in this study patent data is used to construct a proxy measure of technology transfer. This is an approach used by Eaton and Kortum (1999). However, their study uses data from all patent applications, while the focus of this study is on a particular area - environmental technologies. As such it is important to first develop a working definition of environmental technologies which can be applied to patent data.

\subsection{Patent counts as a measure of environment-related innovation}

Patent data have been used as a measure of technological innovation because they focus on outputs of the inventive process (Griliches 1990; OECD 2008). This is in contrast to many other potential candidates (e.g. research and development expenditures, number of scientific personnel, etc.) which are at best imperfect indicators of the innovative performance of an economy since they focus on inputs. Moreover, patent data provide a wealth of information on the nature of the invention and the applicant, the data is readily available (if not always in a convenient format), discrete (and thus easily subject to statistical analysis). Significantly, there are very few examples of economically significant inventions which have not been patented (Dernis and Guellec 2001; OECD 2009). Most importantly for this study, they can be disaggregated to specific technological areas.

Drawing upon existing efforts to define 'environmental' activity in sectoral terms, some previous studies have related patent classes to industrial sectors using concordances (e.g., Jaffe and Palmer 1997). The weaknesses of such approach are twofold. First, if the industry of origin of a patent differs from industry of use of the patent, then it is not clear to which industrial sector a patent should be attributed in the analysis. This is important when studying specifically 'environmental' technology because in this case the demand (users of technology) and supply (inventors of technology) of environmental innovation may involve different entities. Often, 'environmental' innovations originate in industries which are not specifically environmental in their focus. For example, technologies aimed 
at reducing wastewater effluents from the pulp \& paper industry are often invented by the manufacturing or chemicals industry (see e.g., Popp et al. 2007). On the other hand, some 'environmental' industries invent technologies which are widely applicable in non-environmental sectors (e.g., processes for separation of waste; separation of vapours and gases).

More fundamentally, sectoral classifications are, by definition, based on commercial outputs. As such there will be a bias toward the inclusion of patent applications from sectors that produce environmental goods and services. The application-based nature of the patent classification systems allows for a richer characterisation of relevant technologies. Consequently, in this study patent classifications are used, rather than those of industrial or sectoral classifications. ${ }^{11}$ Specifically, relevant patents are identified using the International Patent Classification (IPC) system, developed at the World Intellectual Property Organization (WIPO).

The IPC classes corresponding to the selected 'environmental' technologies are identified in two alternative ways. First, we search the descriptions of the classes online to find those which are appropriate (http://www.wipo.int/classifications/ipc/ipc8/?lang=en). Second, using the online international patent database maintained by the European Patent Office (www.espacenet.com), we search patent titles and abstracts for relevant keywords. The IPC classes corresponding to the patents that come up are included, provided their description confirms their relevancy.

When building the datasets, two possible types of error may arise: irrelevant patents may be included or relevant ones left out. The first error happens if an IPC class includes patents that do not bear the desired 'environmental' focus. In order to avoid this problem, we carefully examine a sample of patent abstracts for every IPC class considered for inclusion, and exclude those classes that do not

\footnotetext{
${ }^{11}$ While Jaffe and Palmer (1997) used patent totals (environmental and non-environmental patents) to study the effect of environmental regulation on innovation, Lanjouw and Mody (1996) and Brunnermeier and Cohen (2003) focus on environmental patents only, and their approach is thus similar to ours. However, details on the selection of IPC classes they used are not always provided.
} 
consist only of patents related to 'environment'. The second error - relevant inventions are left out is less problematic. We can reasonably assume that all innovation in a given field behaves in a similar way and hence our datasets can be seen at worst as good proxies of innovative activity in the field considered. However, overall innovative activity may be underestimated and totals may be less reliable than trends. The description of the IPC codes used to build the datasets for this study can be found in Table A1 in the Appendix.

Patent data were extracted from the EPO World Patent Statistical Database (EPO 2008), or PATSTAT, using a search algorithm based on a selection of IPC classes (Table A1 in the Appendix gives the list of classes included). ${ }^{12}$ The patent data are used to construct counts of patent applications in selected areas of environmental technology (air pollution, water pollution, solid waste), classified by inventor country (country of residence of the inventor) and priority date (the earliest application date within a given patent family). A panel of patent counts for a cross-section of all countries and over a time period of 1975-2006 was obtained. Figure 1 shows the total number of claimed priorities in the three environmental domains. It shows that air pollution control innovations have been increasing rapidly. Innovations related to solid waste disposal reached a peak in 1993 and have declined since. In the case of water pollution control technologies the peak is in the late 1990s.

\footnotetext{
${ }^{12}$ The selection of classifications benefited from searches developed by Lanjouw and Mody (1996) and Schmoch (2003). Assistance of Julie Poirier and Marion Hemar (ENSAE, Paris) in developing the search strategy is equally acknowledged.
} 


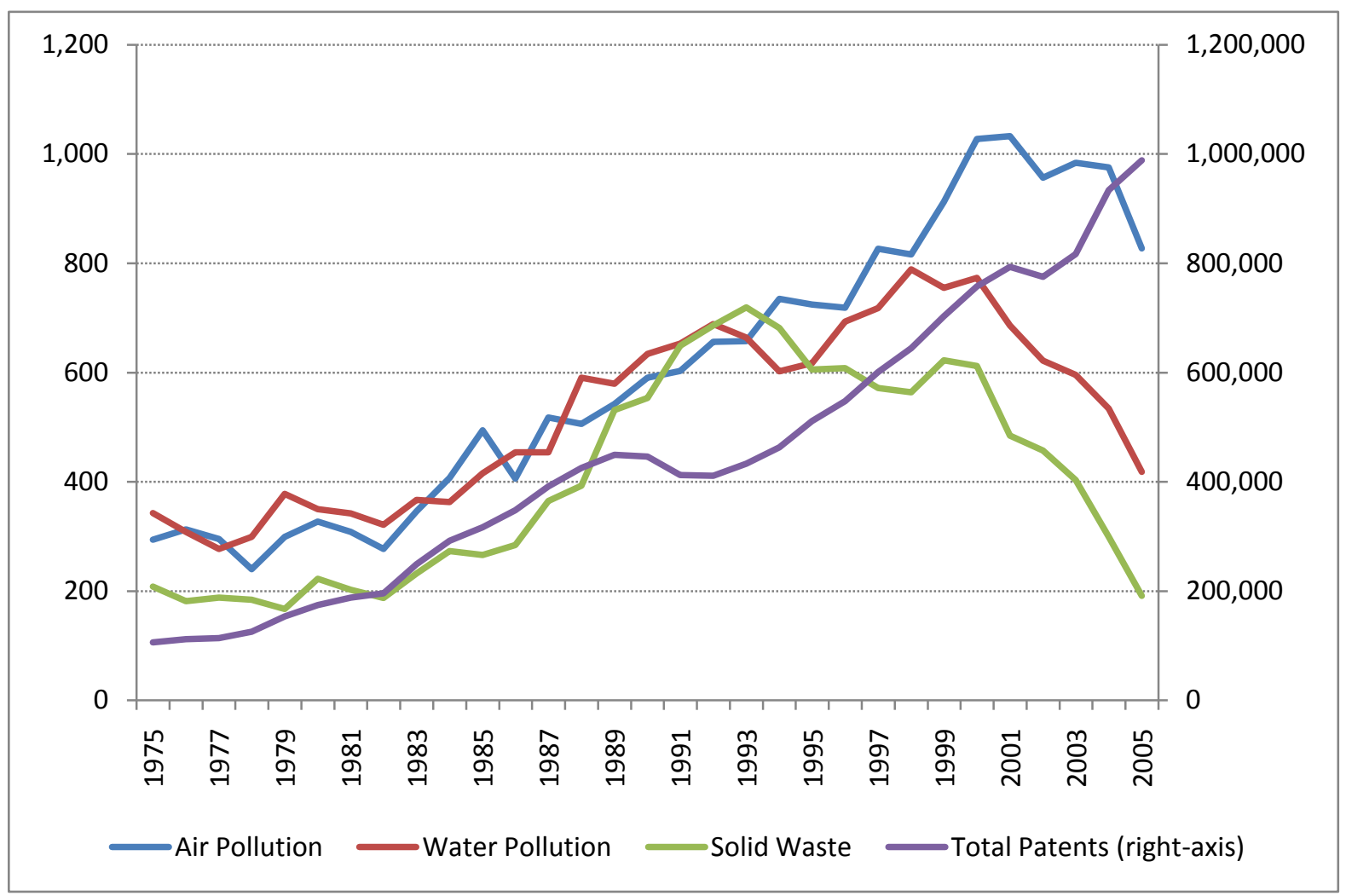

Figure 1. Number of Patent Applications (Claimed Priorities, Worldwide) for 'Environmental' Technologies by Environmental Medium

Figure 2 gives patent counts in environmental technology for selected countries which have exhibited significant levels of innovation. Germany, Japan and the US have the highest number of claimed priorities. While Germany, Japan, the US, France and the UK are consistently important in environmental technologies examined, other significant innovators in specific areas have included Sweden (air), Canada and the Netherlands (water), Italy (waste), and since the late-1990s also Korea (air \& water). 


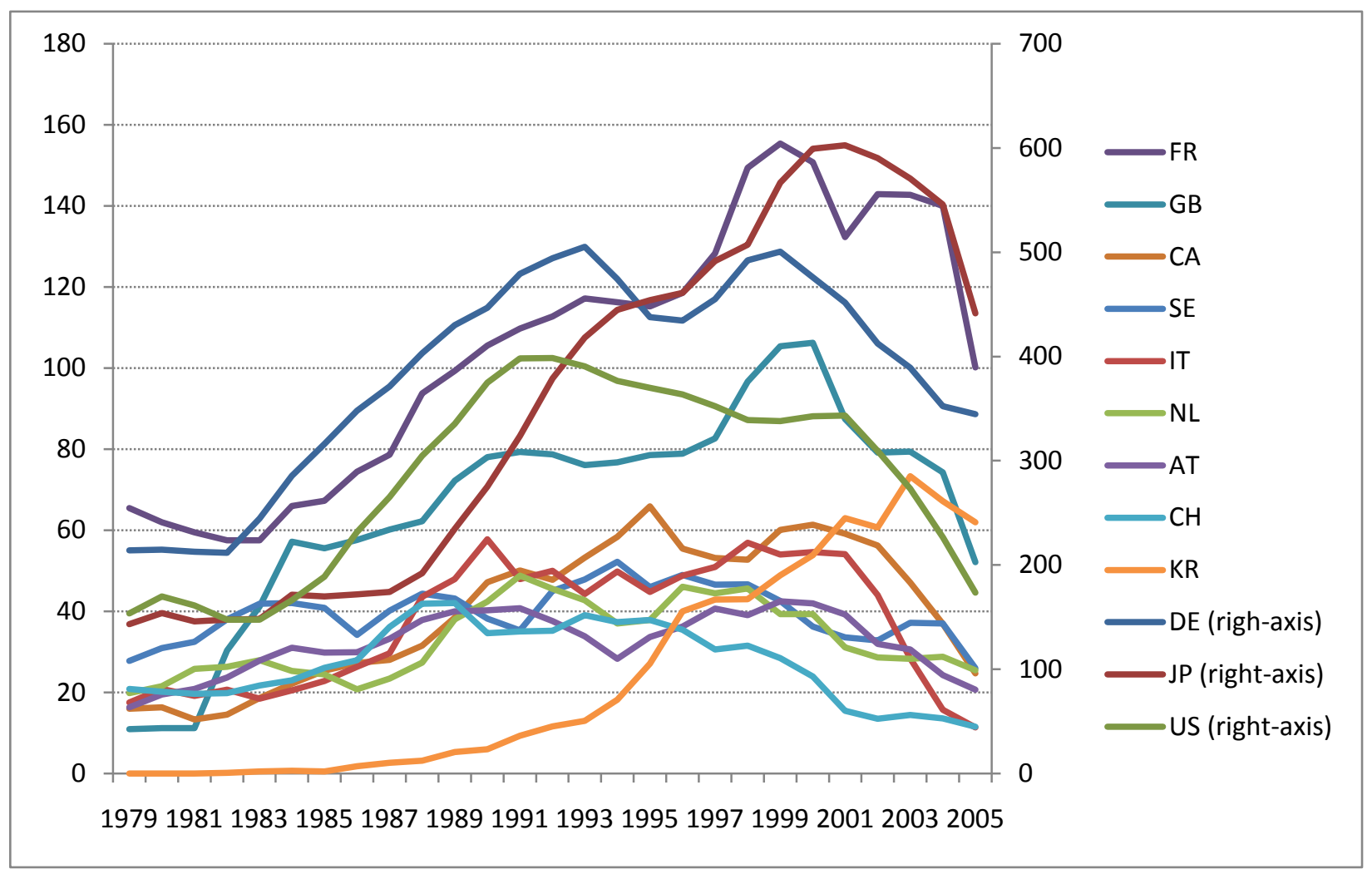

Figure 2. Number of Patent Applications (Claimed Priorities, Worldwide, 3-year moving average) for 'Environmental' Technologies for Selected Countries

\subsection{Duplicate Patent Filings as a Measure of Technology Transfer}

Technology transfer can be either embodied or disembodied, and take place through the market or by non-market means. A possible taxonomy might take the following form (see Maskus 2004 and Hoekman and Javorcik 2006):

- Market

$\begin{array}{ll}\circ & \text { Trade in goods and services } \\ \circ & \text { Foreign direct investment } \\ \circ & \text { Licensing } \\ \circ & \text { Joint ventures } \\ \circ & \text { Cross-border movement of personnel }\end{array}$

- Non-market

- Imitation and reverse engineering

- Employee turnover

○ Published information (journals, test data, patent applications) 
The empirical evidence strongly supports the finding that the bulk of technology transfer takes place via trade, foreign direct investment and licensing (Maskus 2004). Precisely which channel is most important depends in part upon the characteristics of the 'recipient country' (i.e. domestic research capacity, strength of intellectual property rights regimes, etc.) and nature of the technology being 'transferred' (i.e. potential for imitation and reverse engineering). The use of patent data to measure international technology transfer arises from the fact that there will be a partial 'trace' of all three of these channels of transfer in patent applications. If there is any potential for reverse engineering then exporters, investors and licensors have an incentive to protect their intellectual property when it goes overseas.

The potential to use patent data as the base from which to develop a proxy measure of technology transfer arises from the fact that protection for a single invention may be sought in a number of countries. While the vast majority of inventions are only patented in one country (often that of the inventor, particularly for large countries), some are patented in multiple countries (i.e. the 'international patent family size' is greater than one). Such 'duplicate' applications can then be used to develop indicators of technology transfer.

Of course patent only gives the applicant protection from potential imitators. It does not reflect actual transfer of technologies. If applying for protection did not cost anything, inventors might patent widely and indiscriminately. However, patenting is costly - both in terms of the costs of preparation of the application and in terms of the administrative costs and fees associated with the approval procedure (see Helfgott 1993 for some comparative data; Berger (2005) and Van Pottelsberghe and Francois (2006) also provide more recent data for European Patent Office applications). Moreover, if enforcement is weak, the publication of the patent in a local language can increase vulnerability to imitation (see Eaton and Kortum 1996 and 1999). As such, inventors are unlikely to apply for patent 
protection in a second country unless they are relatively certain of the potential market for the technology that the patent covers.

Unfortunately the IPC classifications used in the extraction of patent data do not have precise concordance with trade data classifications. However, the reliability of the use of duplicate patent applications as a measure of technology transfer can be seen through a comparison of one particular type of 'environmental' technology in which trade and patent classifications are similar - wind power. Using data from the UN COMTRADE database (http://comtrade.un.org/db/) it is possible to compare exports of "wind-powered electric generating equipment" (HS 850231) with the count of duplicate patent applications by priority office for "wind motors" (IPC F03D). Figure 3 provides data for the main inventing countries for the period 1996-2003, the only years for which the trade data is available.

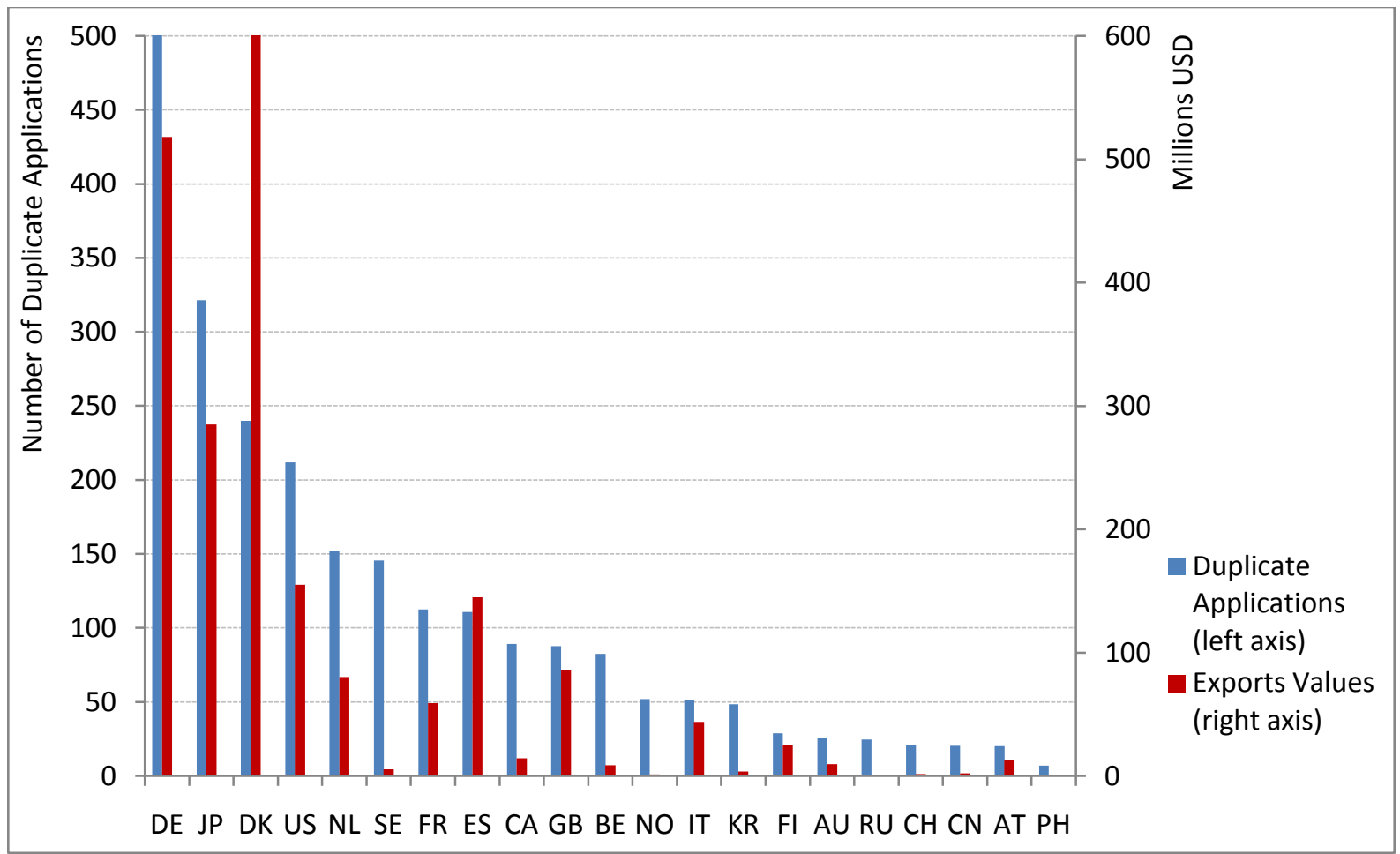

Figure 3. Number of Duplicate Patent Applications and Export of Wind Power Technologies 
While the correlation is not perfect, it is positive and significant. Indeed the top four exporters are also the top four priority offices, and the Spearman rank correlation coefficient for the top 30 countries by trade is 0.68. Moreover, some of the discrepancies may be attributable to shortcomings in COMTRADE's coverage. For instance, for reasons of commercial confidentiality, trade figures for low-level HS classifications may be significantly downward biased. This would explain the number of countries with no apparent exports who are known to be active in the field (e.g. Sweden, Canada, Norway, Switzerland). ${ }^{13}$

We have extracted all relevant patent applications filed from 1975 to 2006. It is common to present patent data in terms of inventor countries (as in Section 3.1 above) in order to measure national inventive activity. However, in this case the data used to contruct the dependent variable is expressed in terms of 'priority offices', since we are concerned with the effect of policy design in different jurisdictions. Applying the definition of environmental technologies developed in Section 3.1, Figure 1 shows the bilateral relations that have included the largest volume of transfer internationally.

Table 1, in turn, lists the bilateral transfer relations that include the highest percentage of 'environmental' innovations.

\footnotetext{
${ }^{13}$ See http://comtrade.un.org/kb/attachments/1.\%20UN\%20Comtrade\%20Coverage\%20and\%20LimitationsGUIDbecc0aa5044f44b5a048a8b45bce6d19.pdf
} 
Figure 1. International Transfer of Selected 'Environmental' Technologies (1990-2005) a. Air pollution abatement

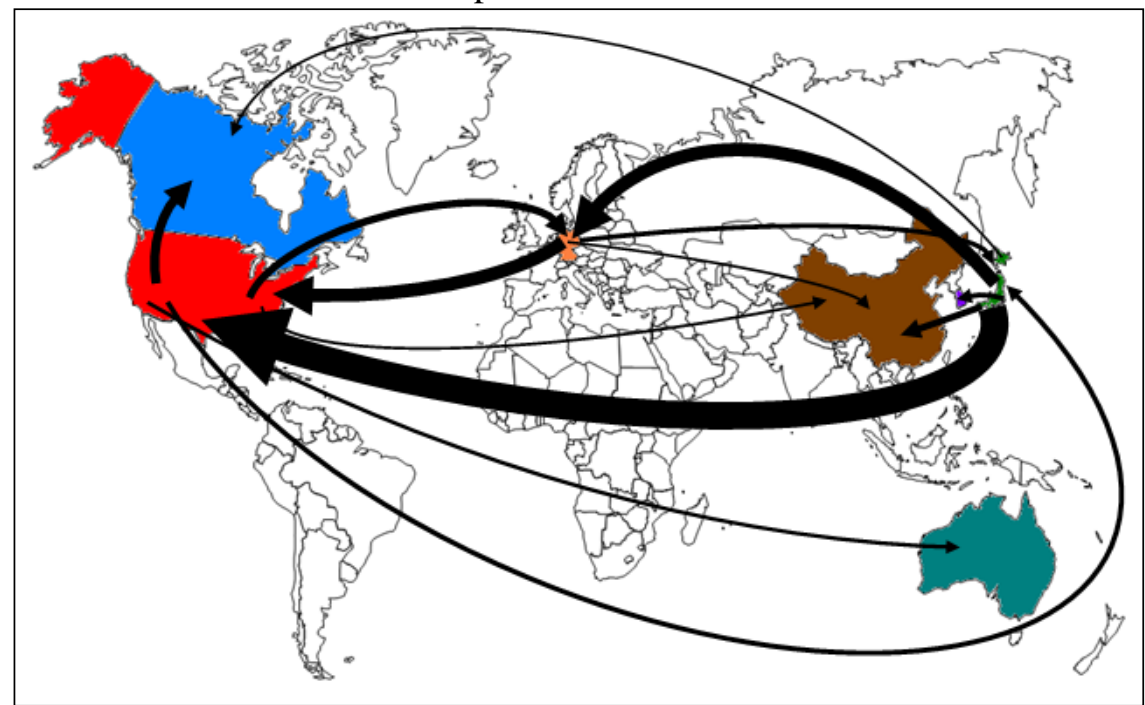

b. Water pollution abatement

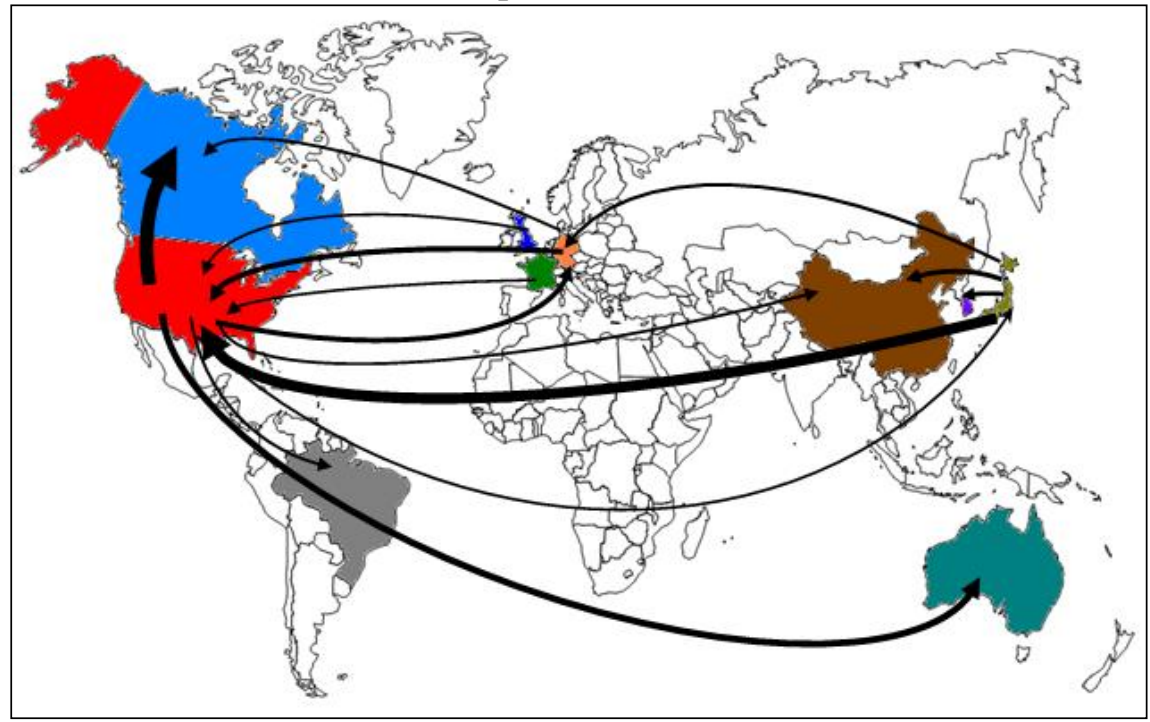

c. Solid waste management

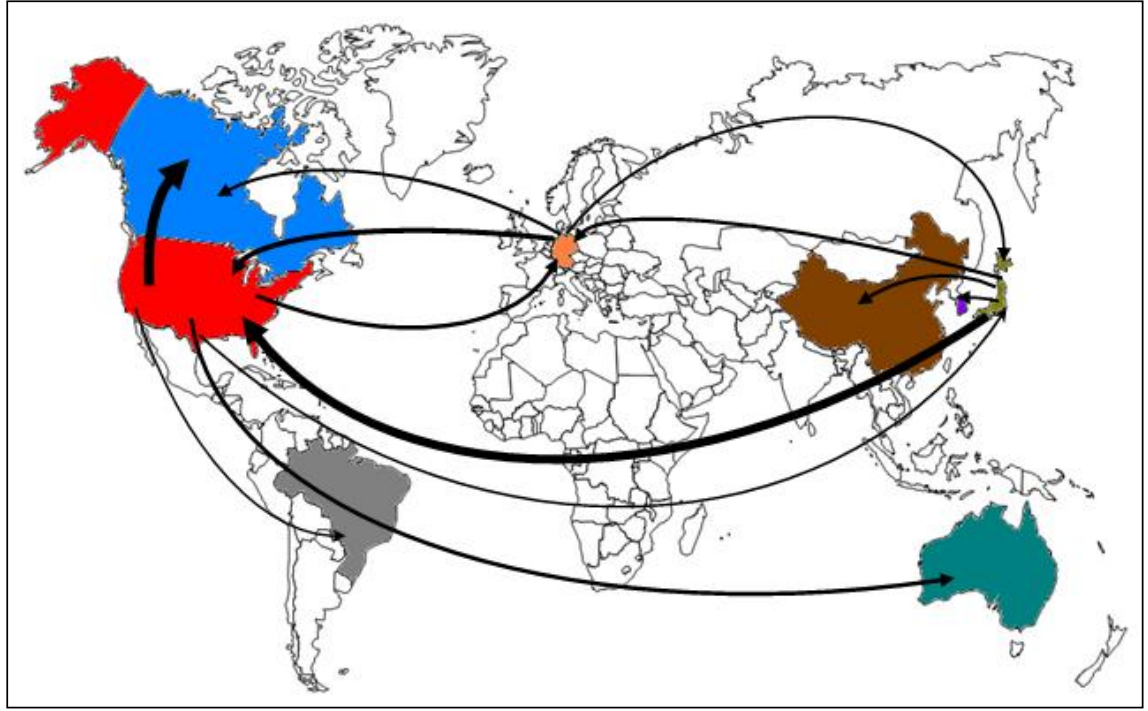


Table 1. The most AWW-intensive bilateral transfer relations

(Number of duplicate patent filings in AWW-relevant fields as a share of overall transfer, 2001-2003)

\begin{tabular}{ccccc}
\hline & & AWW & Total & \\
Source & Recipient & Transfer & Transfer & Share \\
\hline JP & PL & 36 & 191 & $18.85 \%$ \\
NL & BE & 7 & 61 & $11.48 \%$ \\
CZ & SK & 8 & 76 & $10.53 \%$ \\
AT & MX & 8 & 90 & $8.89 \%$ \\
CN & HK & 10 & 122 & $8.20 \%$ \\
AT & PL & 9 & 114 & $7.89 \%$ \\
NO & MX & 5 & 64 & $7.81 \%$ \\
FI & MX & 11 & 142 & $7.75 \%$ \\
PL & AU & 15 & 212 & $7.08 \%$ \\
CZ & AU & 6 & 85 & $7.06 \%$ \\
RU & UA & 8 & 115 & $6.96 \%$ \\
FI & NO & 18 & 259 & $6.95 \%$ \\
JP & ZA & 17 & 246 & $6.91 \%$ \\
FI & PL & 9 & 132 & $6.82 \%$ \\
KR & SG & 4 & 60 & $6.67 \%$ \\
GR & AU & 6 & 92 & $6.52 \%$ \\
CA & NZ & 4 & 62 & $6.45 \%$ \\
UA & RU & 19 & 299 & $6.35 \%$ \\
GB & IE & 6 & 97 & $6.19 \%$ \\
AU & NZ & 46 & 761 & $6.04 \%$ \\
CA & KR & 5 & 83 & $6.02 \%$ \\
AT & BR & 11 & 183 & $6.01 \%$ \\
\hline
\end{tabular}

Note: 'Environmental' technologies covered include: Air + Water + Waste, or AWW. Only bilateral relations with total transfers greater than 50 applications were included.

\subsection{Flexiblity of Environmental Policy}

Given the heterogeneity of environmental policy regimes both across countries, and within countries across sectors and impacts (as well as through time), it is difficult to construct a general index of the ‘flexibility' of environmental policy regimes. However, in the period 2001-2003, the World Economic Forum's "Executive Opinion Survey" asked respondents a number of questions related to environmental policy design. The survey is implemented by the WEF's partner institutes in over 100 countries, which include Departments of Economics in leading universities and research departments of business associations. The means of survey implementation varies by country and includes postal, telephone, internet and face-to-face survey. In most years there are responses from between 8,000 and 10,000 firms (see Sala-i-Martin 2008 for a description of the sampling strategy). 
Specifically, respondents (usually CEOs) were requested to indicate the extent to which they had the freedom to choose different options in order to achieve compliance with environmental regulations. Respondents were requested to assess the degree of flexibility on a Likert scale, with $1=$ offer no options for achieving compliance, $7=$ are flexible and offer many options for achieving compliance. Mean responses for some of the countries included in our sample are provided in Figure 4.

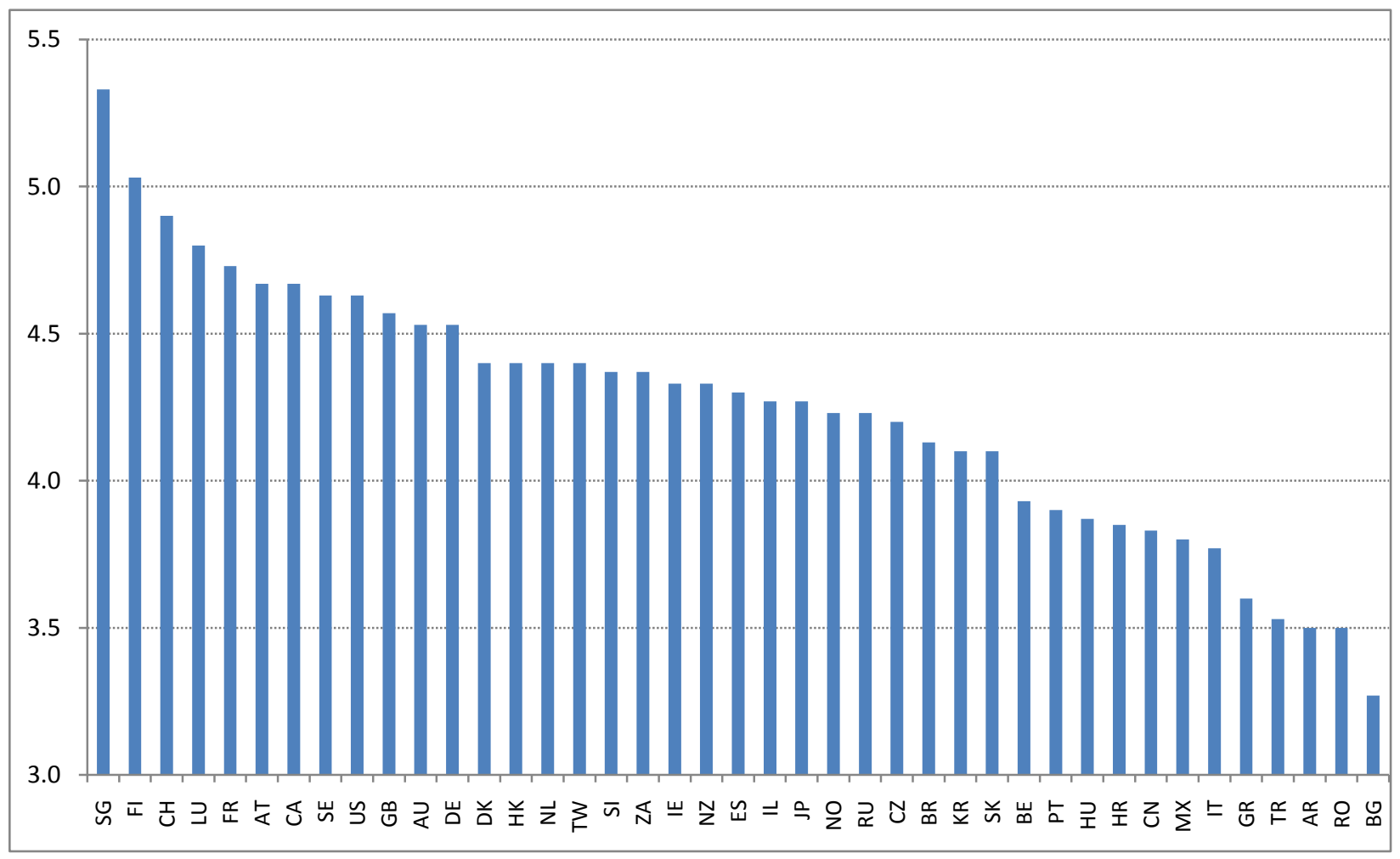

Figure 4. Index of Flexibility of Environmental Policy Regimes for Selected Countries (mean value over 2001-2003)

\subsection{Other explanatory variables}

For a given level of flexibility, the stringency of environmental policy will determine the size of markets for innovation. As such, it may be necessary to control for differences in the stringency of environmental policy across countries and over time. For this purpose, an index of perceived stringency of a country's overall environmental regulation is used (Sala-i-Martin 2008). The degree of 
stringency has been assessed on a Likert scale, with $1=$ lax compared with that of most other countries, $7=$ among the world's most stringent. Mean responses for some of the countries included in our sample are provided in Figure 5.

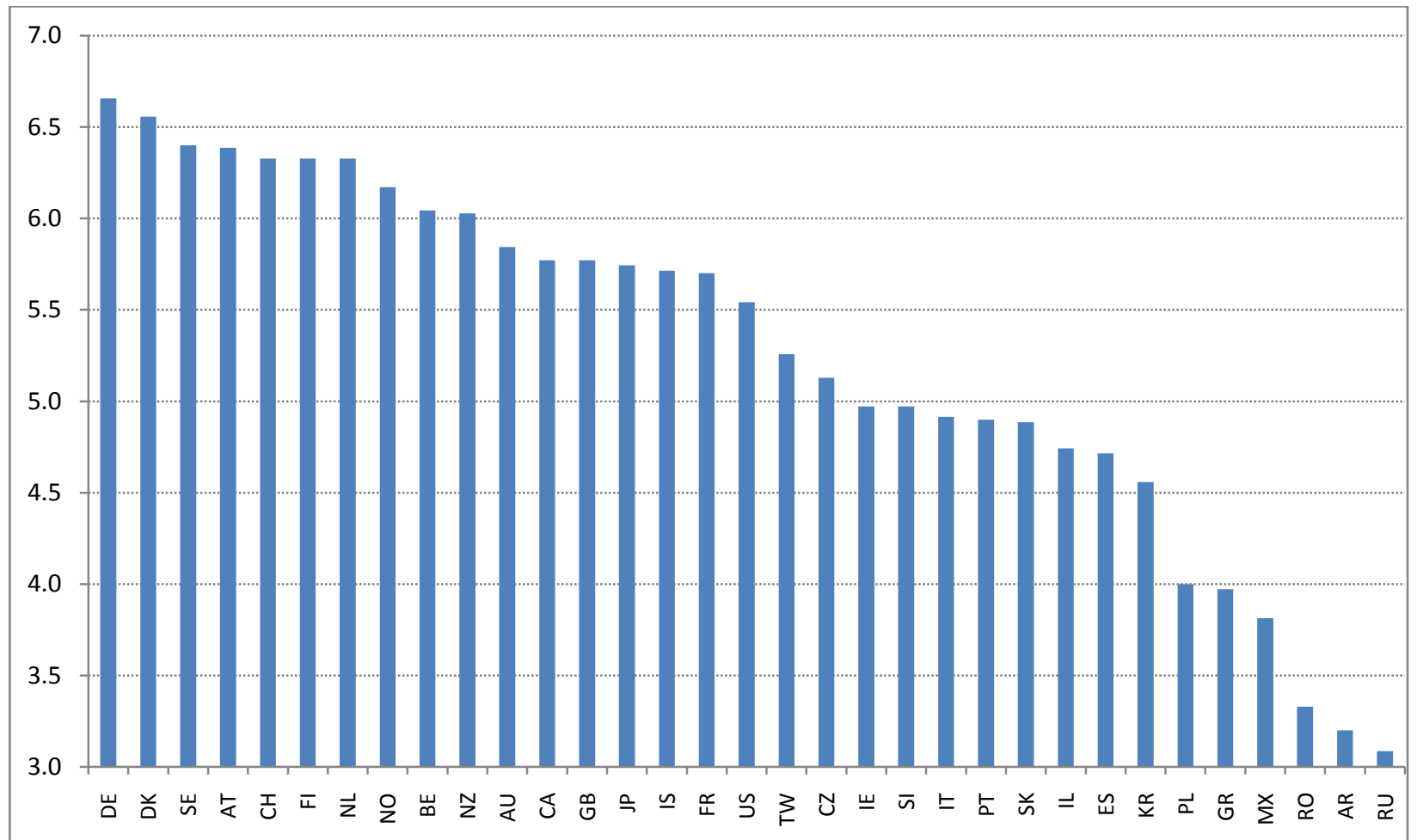

Figure 5. Index of Stringency of Environmental Policy Regimes for Selected Countries (mean value over 2001-2006)

As found in more general studies of technology transfer, domestic absorptive capacity is an important factor. While the number of scientific personnel or expenditures on R\&D in the relevant fields could be used as measures of domestic scientific capacity, in practice the lack of data for many non-OECD countries (even at the macroeconomic level) prohibits the use of such a measure. Therefore, we assume that patent data can also be used to measure absorptive capacity of the recipient country. A count of patented inventions by domestic (i.e. recipient country's) inventors is included for this purpose. 
Technologies may only be transferred if they have been developed in the first place. To capture the stock of inventions in source country that are potentially available for transfer elsewhere, a variable is constructed that reflects the number of patent applications by domestic inventors filed in the current or the three previous years. This time span is appropriate given the limitations on international patenting imposed by international patent treaties. ${ }^{14}$ Thus, the mode of the distribution of transfer lags is between 1 and 2 years, as expected. It must also be noted that, as in the previous case, the entire stock of inventions in PATSTAT is considered when constructing the variable, including inventions for which no claims for protection have been sought in countries other than that of the priority office. The sign of this variable is expected to be positive.

Finally, differences in the general propensity to transfer patents between countries and over time are captured through the use of a variable which reflects overall duplicate patent applications filed across the whole spectrum of technological areas. This variable should capture all of the more general economic factors which are likely to influence transfer (e.g. common language, geographic distance, commercial relations, strength of intellectual property rights, etc.), but which are not specific to 'environmental' innovation. The sign is expected to be positive.

\section{Empirical Model and Results}

Our aim is to analyse the relationship between the nature of policy regimes and technology transfer. To do so, we construct a gravity model which allows us to examine all potential bilateral relations between source and recipient countries. The hypothesis is that, other things being equal, more 'flexible' environmental policy regimes are likely to generate innovations with broad potential acceptance in overseas markets. Figure 5 provides a scatter plot of the relationship between the index

\footnotetext{
${ }^{14}$ Lags associated with filing duplicate applications are, in part, determined by the Paris Convention (1883), stipulating that applications abroad must be filed within one year of the date when the initial application was filed (referred to as 'priority date'). If the inventor does file abroad within one year, the inventor will have priority over any similar patent applications received in those countries since the priority date. In addition, under the Patent Cooperation Treaty (1970) the applicant may file an international application which allows further 18 months to make any duplicate filings in signatory countries.
} 
of the flexibility of environmental policy regimes and the log of 'exports' (outflows) of environmental technologies, suggesting a positive relationship, with the correlation coefficient $=0.45$ (at $<0.001 \%$ significance level).

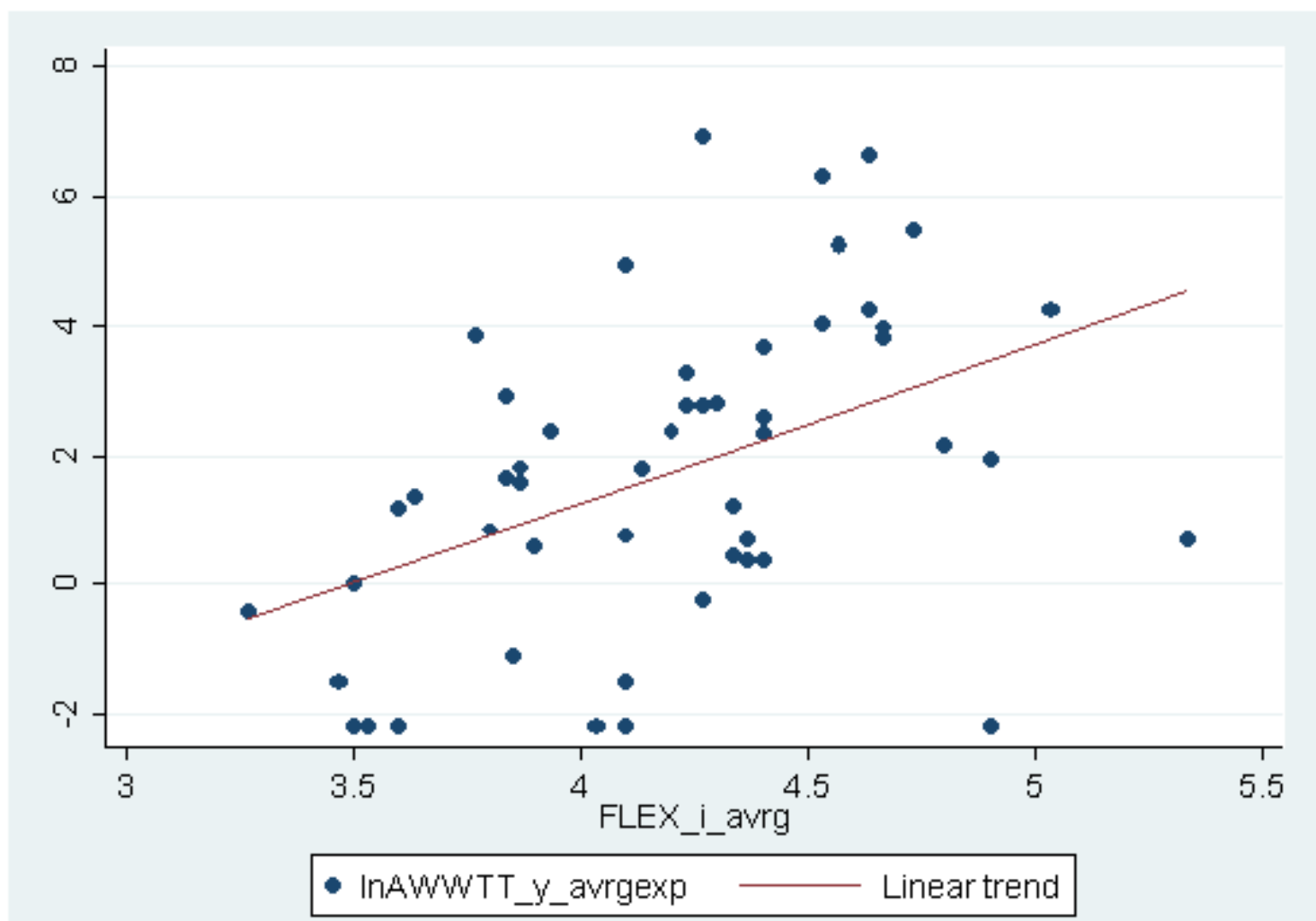

Figure 5. Relationship Between the Flexibility of the Environmental Policy Regimes and 'Exports' (Outflows) of Environmental Technologies

Moreover, countries with more flexible policy regimes are more likely to be able to benefit from inventions developed elsewhere. As such, Figure 6 gives the same information but from the viewpoint of the recipient country. The relationship between the flexibility index and 'imports' (inflows) of environmental technologies is positive, with the correlation coefficient $=0.26$ (at $<0.001 \%$ significance level). 


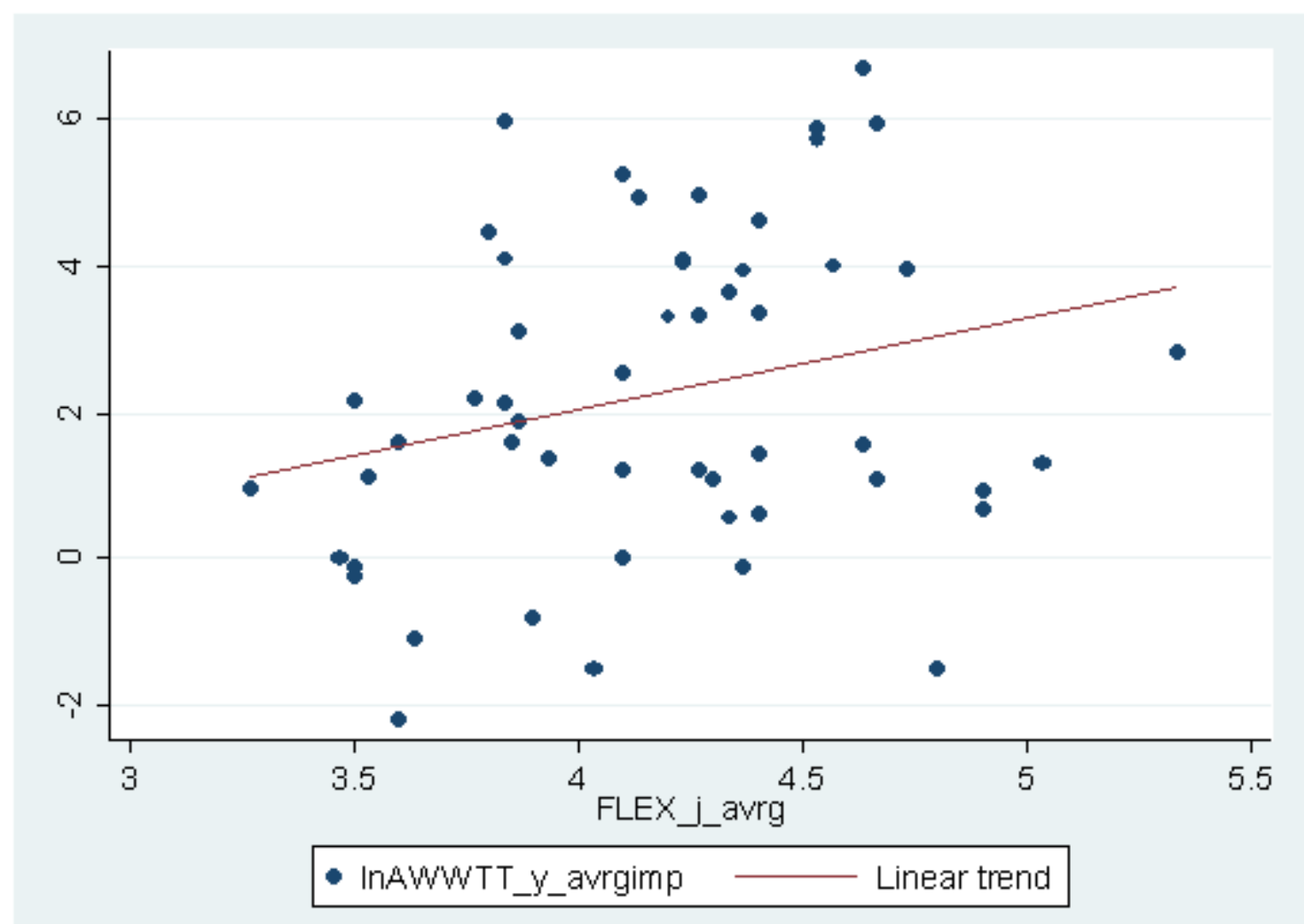

Figure 6. Relationship Between the Flexibility of the Environmental Policy Regimes and 'Imports' (Inflows) of Environmental Technologies

Based on the discussion above, the following equation is specified:

$$
\begin{aligned}
\operatorname{AWWTT}_{\mathrm{ijt}}=\beta_{1} & +\beta_{2} \text { FLEX }_{\mathrm{it}}+\beta_{3} \text { FLEX }_{\mathrm{jt}}+\beta_{4} \text { STRNG }_{\mathrm{it}}+\beta_{5} \text { STRNG }_{\mathrm{jt}} \\
& +\beta_{6} \text { AWWSTOCK }_{\mathrm{it}}+\beta_{7} \text { AWWPAT }_{\mathrm{jt}}+\beta_{8} \text { TOTALTT }_{\mathrm{jt}}+\epsilon_{\mathrm{ijt}}
\end{aligned}
$$

where $i$ represents the source country, $j$ the recipient country ${ }^{15}$, and $t=1998, \ldots, 2006$ indexes time ${ }^{16}$. Our dependent variable is a measure of the number of patents in source country $i$ (the 'priority' office) for which protection has also been sought in recipient country $j$ (the 'duplicate' office) in year $t$. On the right-hand side of the equation, FLEX $\mathrm{it}_{\mathrm{it}}$ and $\mathrm{FLEX}_{\mathrm{jt}}$ reflect the degree of flexibility of the source and recipient country's environmental policy regimes, respectively. It is expected that the sign of these variables is positive. Similarly, $S T R N G_{i t}$ and $S T R N G_{j t}$ reflect the degree of stringency of the source and recipient countries' environmental policy regimes. AWWSTOCK $\mathrm{it}_{\mathrm{it}}$ is the available stock of

\footnotetext{
15 There are 101 source and recipient countries in the sample.

${ }^{16}$ That is, 3 years after and 3 years prior to the availability of data on the flexibility index.
} 
inventions in environment-related technologies measured as the sum of patent applications invented in the source country during the current and the previous three years. The sign is expected to be positive. $\mathrm{AWWPAT}_{\mathrm{jt}}$ is the total number of patent applications for environment-related technologies invented in the recipient country and the expected sign is positive, since increased absorptive capacity should increase transfers. And finally, TOTALTT $\mathrm{ijt}_{\mathrm{i}}$ is the total number of patents which are transferred from source country to recipient country, and sign is expected to be positive. All the residual variation is captured by the error term $\left(\varepsilon_{\mathrm{ijt}}\right)$. Table 2 gives the basic descriptive statistics for the sample used.

Table 2. Descriptive statistics for the panel dataset

\begin{tabular}{lrrrrr}
\hline Variable & Obs & Mean & Std. Dev. & Min & Max \\
\hline AWWTT $_{\text {ijt }}$ & 21822 & 0.57 & 8.27 & 0 & 498 \\
FLEX $_{\text {it }}$ & 21822 & 3.94 & 0.62 & 1.7 & 5.4 \\
FLEX $_{\text {jt }}$ & 21822 & 3.94 & 0.62 & 1.7 & 5.4 \\
STRNG $_{\text {it }}$ & 21822 & 4.12 & 1.31 & 1.2 & 6.7 \\
STRNG $_{\text {jt }}$ & 21822 & 4.12 & 1.31 & 1.2 & 6.7 \\
AWWSTOCK $_{\text {it }}$ & 21822 & 421.25 & 1273.64 & 0 & 7790 \\
AWWPAT $_{\text {it }}$ & 21822 & 109.32 & 329.02 & 0 & 2024 \\
TOTALTT $_{\text {ijt }}$ & 21822 & 42.74 & 768.19 & 0 & 49584 \\
\hline
\end{tabular}

Given the count nature of the dependent variable, the equation is estimated as a negative binomial model using maximum likelihood. ${ }^{17}$ Four alternative model specifications are estimated. This includes models where the flexibility index varies over time, placing a constraint on the length of the panel (models $1 \& 2$ ). Alternatively, the mean value of the index is used instead allowing for longer panel (models $3 \& 4$ ). The empirical results (Table 3) confirm all of our principal hypotheses. Starting with the control variables, the results suggest that the stock of inventions that are potentially available for transfer in the source country, as well as the absorptive capacity of the recipient country, are both important determinants of transfers of 'environmental' technologies. Moreover, such transfer is positively (and significantly) correlated with the volume of technology transfer overall. These results hold for all the alternative models estimated.

\footnotetext{
${ }^{17}$ For further details on negative binomial models, see Cameron and Trivedi (1998); Hausman, Hall and Griliches (1984).
} 
When it comes to characterization of the differences in policy regimes between the source and recipient countries, the results suggest that countries with more flexible policy measures are both, more likely to be able to 'export' their inventions to markets abroad, as well as benefit from inventions already developed elsewhere. The estimated coefficients are positive and highly significant in all models estimated. ${ }^{18}$ Moreover, controlling for differences in policy stringency (or not) does not affect the qualitative nature of this finding.

Table 3. Empirical estimates of the negative binomial model

\begin{tabular}{|c|c|c|c|c|}
\hline \multirow{3}{*}{ Dependent variable: $\mathrm{AWWTT}_{\mathrm{ijt}}$} & \multirow{2}{*}{\multicolumn{2}{|c|}{$\begin{array}{l}\text { using } \text { FLEX }_{\mathrm{jt}} \\
\mathrm{t}=2001-03\end{array}$}} & \multicolumn{2}{|c|}{ using FLEX $_{\mathrm{j} \_a v g}$} \\
\hline & & & \multirow{2}{*}{$\begin{array}{c}\mathrm{t}=1998-06 \\
\text { (3) }\end{array}$} & \multirow{2}{*}{$\begin{array}{c}t=2001-06 \\
(4)\end{array}$} \\
\hline & $(1)$ & (2) & & \\
\hline Policy Flexibility $\left(\mathrm{FLEX}_{\mathrm{it}}\right.$ or FLEX $\left._{\mathrm{i} \_ \text {avg }}\right)$ & $\begin{array}{l}1.3657 * * * \\
(0.000)\end{array}$ & $\begin{array}{l}0.2204 \\
(0.102)\end{array}$ & $\begin{array}{l}2.1638 * * * \\
(0.000)\end{array}$ & $\begin{array}{l}0.5966^{* * * *} \\
(0.000)\end{array}$ \\
\hline Policy Flexibility $\left(\mathrm{FLEX}_{\mathrm{jt}}\right.$ or $\left.\mathrm{FLEX}_{\mathrm{j} \_ \text {avg }}\right)$ & $\begin{array}{l}1.0634 * * * \\
(0.000)\end{array}$ & $\begin{array}{l}0.6256 * * * \\
(0.000)\end{array}$ & $\begin{array}{l}1.4522 * * * \\
(0.000)\end{array}$ & $\begin{array}{l}1.1998^{* * *} \\
(0.000)\end{array}$ \\
\hline Policy Stringency $\left(\mathrm{STRNG}_{\mathrm{it}}\right)$ & & $\begin{array}{l}0.8262 * * * \\
(0.000)\end{array}$ & & $\begin{array}{l}0.6698 * * * \\
(0.000)\end{array}$ \\
\hline Policy Stringency $\left(\mathrm{STRNG}_{\mathrm{jt}}\right)$ & & $\begin{array}{l}0.3354 * * * \\
(0.000)\end{array}$ & & $\begin{array}{l}0.1202 * \\
(0.047)\end{array}$ \\
\hline Available Stock of Inventions (AWWSTOCK ${ }_{\text {it }}$ ) & $\begin{array}{l}0.0004^{* * * *} \\
(0.000)\end{array}$ & $\begin{array}{l}0.0003 \text { *** } \\
(0.000)\end{array}$ & $\begin{array}{l}0.0003^{* * * *} \\
(0.000)\end{array}$ & $\begin{array}{l}0.0003 * * * \\
(0.000)\end{array}$ \\
\hline Absorptive Capacity (AWWPAT $\mathrm{At}_{\mathrm{jt}}$ ) & $\begin{array}{l}0.0012 * * * \\
(0.000)\end{array}$ & $\begin{array}{l}0.0012 * * * \\
(0.000)\end{array}$ & $\begin{array}{l}0.0011 * * * \\
(0.000)\end{array}$ & $\begin{array}{l}0.0011 \text { *** } \\
(0.000)\end{array}$ \\
\hline Total Technology Transfer $\left(\right.$ TOTALTT $_{\mathrm{ijt}}$ ) & $\begin{array}{l}0.0042 * * * \\
(0.000)\end{array}$ & $\begin{array}{l}0.0026 * * * \\
(0.000)\end{array}$ & $\begin{array}{l}0.0044 * * * \\
(0.000)\end{array}$ & $\begin{array}{l}0.0028 * * * \\
(0.000)\end{array}$ \\
\hline Intercept & $\begin{array}{l}-13.2789 * * * \\
(0.000)\end{array}$ & $\begin{array}{l}-12.1151 * * * \\
(0.000)\end{array}$ & $\begin{array}{l}-18.6560 * * * \\
(0.000)\end{array}$ & $\begin{array}{l}-14.7467 * * * \\
(0.000)\end{array}$ \\
\hline $\mathrm{N}$ & 21822 & 21822 & 90900 & 37200 \\
\hline Log pseudolikelihood & -5757.94 & -5548.51 & -15888.29 & -8035.44 \\
\hline$($ Prob $>$ Chi2) & 0.000 & 0.000 & 0.000 & 0.000 \\
\hline
\end{tabular}

P-values in parentheses, based on robust standard errors. * $\mathrm{p}<0.05, * * \mathrm{p}<0.01, * * * \mathrm{p}<0.001$

${ }^{18}$ The only exception is model (2), where the significance level is $10.2 \%$. However, the principal results are confirmed when year fixed effects are included (Table 4). 
We note that the findings are robust to the inclusion of year fixed effects (Table 4). Convergence problems prevented us from including year fixed effects for the two models with the full sample, as well as country fixed effects. However, country-specific heterogeneity is already controlled for by a number of regressors in the model that vary across individual country.

Table 4. Empirical estimates of the negative binomial model, with year fixed effects

\begin{tabular}{|c|c|c|}
\hline \multirow[t]{2}{*}{ Dependent variable: AWWTT $_{\mathrm{ijt}}$} & \multicolumn{2}{|c|}{$\begin{array}{l}\text { using } \text { FLEX }_{\mathrm{jt}} \\
\mathrm{t}=2001-03\end{array}$} \\
\hline & $(1)$ & $(2)$ \\
\hline 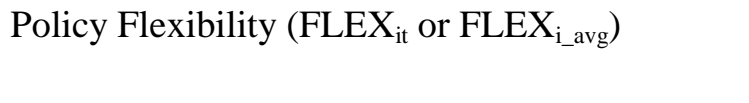 & $\begin{array}{l}1.5741 * * * \\
(0.000)\end{array}$ & $\begin{array}{l}0.4906^{* * * *} \\
(0.000)\end{array}$ \\
\hline Policy Flexibility (FLEX $\mathrm{jt}_{\mathrm{jt}}$ or FLEX $\left._{\mathrm{j} \_\mathrm{avg}}\right)$ & $\begin{array}{l}1.2925 * * * \\
(0.000)\end{array}$ & $\begin{array}{l}0.9103 * * * \\
(0.000)\end{array}$ \\
\hline Policy Stringency $\left(\mathrm{STRNG}_{\mathrm{it}}\right)$ & & $\begin{array}{l}0.7329 * * * \\
(0.000)\end{array}$ \\
\hline Policy Stringency $\left(\mathrm{STRNG}_{\mathrm{jt}}\right)$ & & $\begin{array}{l}0.2513 * * * \\
(0.000)\end{array}$ \\
\hline Available Stock of Inventions (AWWSTOCK ${ }_{i t}$ ) & $\begin{array}{l}0.0004 * * * \\
(0.000)\end{array}$ & $\begin{array}{l}0.0003 * * * \\
(0.000)\end{array}$ \\
\hline Absorptive Capacity $\left(\mathrm{AWWPAT}_{\mathrm{jt}}\right)$ & $\begin{array}{l}0.0012 * * * \\
(0.000)\end{array}$ & $\begin{array}{l}0.0012 * * * \\
(0.000)\end{array}$ \\
\hline Total Technology Transfer $\left(\right.$ TOTALTT $\left._{\mathrm{ijt}}\right)$ & $\begin{array}{l}0.0034 * * * \\
(0.000)\end{array}$ & $\begin{array}{l}0.0024 * * * \\
(0.000)\end{array}$ \\
\hline Intercept & $\begin{array}{l}-14.4582 * * * \\
(0.000)\end{array}$ & $\begin{array}{l}-13.1599 * * * \\
(0.000)\end{array}$ \\
\hline $\mathrm{N}$ & 21822 & 21822 \\
\hline Log pseudolikelihood & -5644.45 & -5494.47 \\
\hline$($ Prob $>$ Chi2 $)$ & 0.000 & 0.000 \\
\hline
\end{tabular}




\section{Conclusions and Policy Implications}

In this paper it has been argued that 'differentiated' and 'prescriptive' technology-based regulations can result in fragmented technology markets, with the potential market for the innovations induced fragmented across different policy jurisdictions. International policy coordination would reduce the potential for such fragmentation. For global public goods (such as mitigation of climate change) such coordination is evident. The European Union's Emissions Trading Scheme is the most significant example. However, even for greenhouse gas emissions within Europe, this is the exception and not the rule. For many sources there a myriad of differentiated and prescriptive policy measures.

The problem is, of course, more important in the case of local and regional pollutans. Indeed, the imposition of uniform standards across countries with different ecological and economic conditions would not likely be welfare-improving. However, this does not mean that the benefits associated with globalised markets for innovation can not be realised. In effect, it is 'flexiblity' of policy regimes (rather than relative stringency) which ensures that markets are not fragmented. Given the risks associated with expenditures on research and development, and the economies of scale required to recover such expenditures, it is important that regulatory regimes not constrain the potential markets for any innovations induced.

This flexibility is primarily a consequence of the point of incidence of different policy measures. Any policy which focuses on the environmental 'bad', rather than mandating a particular means of reducing its impact, will provide potential innovators with the flexibility to identify the optimal means of its mitigation. This can include performance standards as well as market-based instruments such as environmentally related taxes and tradable permits. The key is that the policy measure be 'technologyneutral' in the sense that innovators have the choice of technology to use to meet a given environmental objective (e.g. $\mathrm{SO}_{2}$ emission levels, wastewater effluent quality). 
Drawing upon a rich database of patent applications, results on the effects of environmental policy design on the international transfer of environmental technologies have been presented. There appears to be a strong relationship between CEO's perception of the flexibility of environmental policy regimes in different countries and the spatial scope of diffusion of inventions which are first patented in these countries. These results provide further support for the the use of 'flexible' instruments (including market-based instruments) in environmental policy. And while the focus of this paper is on the specific case of environmental policy, the discussion is equally applicable to aspects of product and labour market regulation which have implications for technological innovation, such as product and workplace safety. 


\section{References}

Brunnermeier, S.B. and M.A. Cohen. (2003). "Determinants of environmental innovation in US manufacturing industries". Journal of Environmental Economics and Management 45: 278-293.

Cameron, A.C. and P.K. Trivedi. 1998. Regression analysis of count data. Cambridge University Press, Cambridge.

Chakravorty, U. and C. Nauges (2005). "Boutique Fuels and Market Power". (February 2005). Available at SSRN: http://ssrn.com/abstract=734407.

Chakravorty, U., C. Nauges and A. Thomas (2007). "Clean Air Regulation and Heterogeneity in US Gasoline Prices". Journal of Environmental Economics and Management.

De Coninck, H. et al. (2008). "International Technology-Oriented Agreements to Address Climate Change”. Energy Policy vol. 36, pp. 335-356.

Dernis, H. and D. Guellec (2001). "Using Patent Counts for Cross-Country Comparisons of Technology Output". STI Review 27 (http://www.oecd.org/LongAbstract/0,3425,en $264933703 \quad 21682516 \quad 1 \quad 1 \quad 1 \quad 1,00 . h t m l)$.

Downing, P.B. and L.J. White (1986). "Innovation in Pollution Control". Journal of Environmental Economics and Management Vol. 13, pp. 18-29.

Eaton, J. and S. Kortum (1996). "Trade in ideas Patenting and productivity in the OECD". Journal of International Economics Vol. 40, Issues 3-4, pp. 251-278.

Eaton, J. and S. Kortum (1999). "International Technology Diffusion: Theory and Measurement". International Economic Review, Vol. 40, No. 3, pp. 537-570.

EPO Worldwide Patent Statistical Database (PATSTAT), October 2008 version.

Fredriksson, P.G. and D.L. Millimet (2002). "Is there a 'California effect' in US environmental policymaking?" in Regional Science and Urban Economics 32 (6): 737-764.

Greaker, M. and H. Eggert (2008). "GMO food in the European Union: Are policies likely to be protectionist?" Entwined Working Paper (2008) (http://www.entwined.se).

Griliches, Z. (1990). "Patent statistics as economic indicators: a survey". Journal of Economic Literature 28(4): 1661-1707.

Hausman, J., B.H. Hall and Z. Griliches. 1984. Econometric models for count data with an application to the patents-R\&D relationship. Econometrica 52: 909-938.

Helfgott, S. (1993). "Patent filing costs around the world". Journal of the Patent and Trademark Office Society, July, pp. 567-580.

Hoekman, B. and B.S. Javorcik (2006). Global Integration and Technology Transfer (London: Palgrave MacMillan)

Jaffe, A.B, R. Newell and R.N. Stavins (2002). "Technological change and the environment". Environmental and Resources Economics 22: 41-69.

Jaffe, A.B. and K. Palmer. (1997). "Environmental regulation and innovation: a panel data study". The Review of Economics and Statistics 79(4): 610-619.

Jung, C. et al. (1996). "Incentives for Advanced Pollution Abatement Technology at the Industry Level”. Journal of Environmental Economics and Management, Vol. 30, pp. 95-111.

Lanjouw, J.O. and A. Mody.(1996). "Innovation and the international diffusion of environmentally responsive technology" in Research Policy 25(5): 49-571. 
Levinson, A. and M.S. Taylor (2008). "Unmasking the Pollution Haven Effect". International Economic Review 49 (1), 223-254.

Maskus, K.E. (2004). “Encouraging International Technology Transfer”. UNCTAD/ICTSD Project on IPRS and Sustainable Development, Issue Paper No. 7.

Milliman, S.R. and R. Prince (1989) "Firm Incentives to Promote Technological Change in Pollution Control" in Journal of Environmental Economics and Management Vol. 17, pp. 247-265

Morriss, A.P. and N. Stewart (2006). "Market Fragmenting Regulation: Why Gasoline Costs so Much (and Why it's Going to Cost Even More)" (September 2006). Illinois Public Law Research Paper No. 06-11 Available at SSRN: http://ssrn.com/abstract=928503

Nentjes, A. and D. Wiersma (1987) "Innovation and Pollution Control" in International Journal of Social Economics Vol. 15, pp. 51-71

OECD. 2008. Environmental Policy, Technological Innovation and Patents. Paris: OECD.

OECD. (2009) OECD Patent Statistics Manual (Paris, 2009).

Popp, D., T. Hafner and N. Johnstone. (2007). "Policy vs. Consumer Pressure: Innovation and Diffusion of Alternative Bleaching Technologies in the Pulp Industry". NBER Working Paper \#13439 (www.nber.org).

Sala-i-Martin, X. et al. (2008) The Global Competititveness Report (Oxford : OUP)

Schmoch, U.(2003). "Definition of patent search strategies for selected technological areas": Report to the OECD. Frauenhofer ISI, Karlsruhe, Germany.

Shy, Oz (2001). The Economics of Network Industries (Cambridge: CUP, 2001)

Sykes, A. (1995) Product Standards for Internationally Integrated Goods Markets, The Brookings Institution, Washington, D.C.

Thilmany, D.D. and C.B. Barrett (1997). "Regulatory Barriers in an Integrating World Food Market". Review of Agricultural Economics, Vol. 19, No. 1 (Spring - Summer, 1997), pp. 91-107.

Vogel, D. (1998). "The Globalisation of Pharmaceutical Regulation" in Governance: An International Journal of Policy and Administration, Vol. 11, No. 1, January.

Vollebergh, H. (2007). Impacts of Environmental Policy Instruments on Technological Change. Report for Joint Meetings of Tax and Environment Experts. OECD Environment Directorate Working Paper COM/ENV/EPOC/CTPA/CFA(2006)36/FINAL. Paris: OECD. 


\section{CESifo Working Paper Series}

for full list see www.cesifo-group.org/wp

(address: Poschingerstr. 5, 81679 Munich, Germany, office@cesifo.de)

2565 Patricia Apps, Ngo Van Long and Ray Rees, Optimal Piecewise Linear Income Taxation, February 2009

2566 John Whalley and Shunming Zhang, On the Arbitrariness of Consumption, February 2009

2567 Marie-Louise Leroux, Endogenous Differential Mortality, Non-Contractible Effort and Non Linear Taxation, March 2009

2568 Joanna Bęza-Bojanowska and Ronald MacDonald, The Behavioural Zloty/Euro Equilibrium Exchange Rate, March 2009

2569 Bart Cockx and Matteo Picchio, Are Short-Lived Jobs Stepping Stones to Long-Lasting Jobs?, March 2009

2570 David Card, Jochen Kluve and Andrea Weber, Active Labor Market Policy Evaluations: A Meta-analysis, March 2009

2571 Frederick van der Ploeg and Anthony J. Venables, Harnessing Windfall Revenues: Optimal Policies for Resource-Rich Developing Economies, March 2009

2572 Ondřej Schneider, Reforming Pensions in Europe: Economic Fundamentals and Political Factors, March 2009

2573 Jo Thori Lind, Karl Ove Moene and Fredrik Willumsen, Opium for the Masses? Conflict-Induced Narcotics Production in Afghanistan, March 2009

2574 Silvia Marchesi, Laura Sabani and Axel Dreher, Agency and Communication in IMF Conditional Lending: Theory and Empirical Evidence, March 2009

2575 Carlo Altavilla and Matteo Ciccarelli, The Effects of Monetary Policy on Unemployment Dynamics under Model Uncertainty - Evidence from the US and the Euro Area, March 2009

2576 Falko Fecht, Kjell G. Nyborg and Jörg Rocholl, The Price of Liquidity: Bank Characteristics and Market Conditions, March 2009

2577 Giorgio Bellettini and Filippo Taddei, Real Estate Prices and the Importance of Bequest Taxation, March 2009

2578 Annette Bergemann and Regina T. Riphahn, Female Labor Supply and Parental Leave Benefits - The Causal Effect of Paying Higher Transfers for a Shorter Period of Time, March 2009 
2579 Thomas Eichner and Rüdiger Pethig, EU-Type Carbon Emissions Trade and the Distributional Impact of Overlapping Emissions Taxes, March 2009

2580 Antonios Antypas, Guglielmo Maria Caporale, Nikolaos Kourogenis and Nikitas Pittis, Selectivity, Market Timing and the Morningstar Star-Rating System, March 2009

2581 António Afonso and Christophe Rault, Bootstrap Panel Granger-Causality between Government Budget and External Deficits for the EU, March 2009

2582 Bernd Süssmuth, Malte Heyne and Wolfgang Maennig, Induced Civic Pride and Integration, March 2009

2583 Martin Peitz and Markus Reisinger, Indirect Taxation in Vertical Oligopoly, March 2009

2584 Petra M. Geraats, Trends in Monetary Policy Transparency, March 2009

2585 Johannes Abeler, Armin Falk, Lorenz Götte and David Huffman, Reference Points and Effort Provision, March 2009

2586 Wolfram F. Richter, Taxing Education in Ramsey’s Tradition, March 2009

2587 Yin-Wong Cheung, Menzie D. Chinn and Eiji Fujii, China's Current Account and Exchange Rate, March 2009

2588 Alexander Haupt and Silke Uebelmesser, Voting on Labour-Market Integration and Education Policy when Citizens Differ in Mobility and Ability, March 2009

2589 Hans Jarle Kind, Marko Koethenbuerger and Guttorm Schjelderup, Should UtilityReducing Media Advertising be Taxed?, March 2009

2590 Alessandro Cigno, How to Avoid a Pension Crisis: A Question of Intelligent System Design, March 2009

2591 Helmut Lütkepohl and Fang Xu, The Role of the Log Transformation in Forecasting Economic Variables, March 2009

2592 Rainald Borck, Hyun-Ju Koh and Michael Pflüger, Inefficient Lock-in and Subsidy Competition, March 2009

2593 Paolo M. Panteghini, On the Equivalence between Labor and Consumption Taxation, March 2009

2594 Bruno S. Frey, Economists in the PITS?, March 2009

2595 Natalie Chen and Dennis Novy, International Trade Integration: A Disaggregated Approach, March 2009

2596 Frédérique Bec and Christian Gollier, Term Structure and Cyclicity of Value-at-Risk: Consequences for the Solvency Capital Requirement, March 2009 
2597 Carsten Eckel, International Trade and Retailing, March 2009

2598 Gianni De Nicolò and Iryna Ivaschenko, Global Liquidity, Risk Premiums and Growth Opportunities, March 2009

2599 Jay Pil Choi and Heiko Gerlach, International Antitrust Enforcement and Multi-Market Contact, March 2009

2600 Massimo Bordignon and Guido Tabellini, Moderating Political Extremism: Single Round vs Runoff Elections under Plurality Rule, April 2009

2601 Ana B. Ania and Andreas Wagener, The Open Method of Coordination (OMC) as an Evolutionary Learning Process, April 2009

2602 Simon Gächter, Daniele Nosenzo, Elke Renner and Martin Sefton, Sequential versus Simultaneous Contributions to Public Goods: Experimental Evidence, April 2009

2603 Philippe Jehiel and Andrew Lilico, Smoking Today and Stopping Tomorrow: A Limited Foresight Perspective, April 2009

2604 Andreas Knabe, Steffen Rätzel, Ronnie Schöb and Joachim Weimann, Dissatisfied with Life, but Having a Good Day: Time-Use and Well-Being of the Unemployed, April 2009

2605 David Bartolini and Raffaella Santolini, Fiscal Rules and the Opportunistic Behaviour of the Incumbent Politician: Evidence from Italian Municipalities, April 2009

2606 Erkki Koskela and Jan König, Can Profit Sharing Lower Flexible Outsourcing? A Note, April 2009

2607 Michel Beine, Frédéric Docquier and Çağlar Özden, Diasporas, April 2009

2608 Gerd Ronning and Hans Schneeweiss, Panel Regression with Random Noise, April 2009

2609 Adam S. Booij, Bernard M.S. van Praag and Gijs van de Kuilen, A Parametric Analysis of Prospect Theory's Functionals for the General Population, April 2009

2610 Jeffrey R. Brown, Julia Lynn Coronado and Don Fullerton, Is Social Security Part of the Social Safety Net?, April 2009

2611 Ali Bayar and Bram Smeets, Economic, Political and Institutional Determinants of Budget Deficits in the European Union, April 2009

2612 Balázs Égert, The Impact of Monetary and Commodity Fundamentals, Macro News and Central Bank Communication on the Exchange Rate: Evidence from South Africa, April 2009

2613 Michael Melvin, Christian Saborowski, Michael Sager and Mark P. Taylor, Bank of England Interest Rate Announcements and the Foreign Exchange Market, April 2009 
2614 Marie-Louise Leroux, Pierre Pestieau and Gregory Ponthiere, Should we Subsidize Longevity?, April 2009

2615 Ronald MacDonald, Lukas Menkhoff and Rafael R. Rebitzky, Exchange Rate Forecasters' Performance: Evidence of Skill?, April 2009

2616 Frederick van der Ploeg and Steven Poelhekke, The Volatility Curse: Revisiting the Paradox of Plenty, April 2009

2617 Axel Dreher, Peter Nunnenkamp, Hannes Öhler and Johannes Weisser, Acting Autonomously or Mimicking the State and Peers? A Panel Tobit Analysis of Financial Dependence and Aid Allocation by Swiss NGOs, April 2009

2618 Guglielmo Maria Caporale, Roman Matousek and Chris Stewart, Rating Assignments: Lessons from International Banks, April 2009

2619 Paul Belleflamme and Martin Peitz, Asymmetric Information and Overinvestment in Quality, April 2009

2620 Thomas Dohmen, Armin Falk, David Huffman and Uwe Sunde, Are Risk Aversion and Impatience Related to Cognitive Ability?, April 2009

2621 Yin-Wong Cheung and Xingwang Qian, The Empirics of China's Outward Direct Investment, April 2009

2622 Frédérique Bec and Christian Gollier, Assets Returns Volatility and Investment Horizon: The French Case, April 2009

2623 Ronnie Schöb and Marcel Thum, Asymmetric Information Renders Minimum Wages Less Harmful, April 2009

2624 Martin Ruf and Alfons J. Weichenrieder, The Taxation of Passive Foreign Investment Lessons from German Experience, April 2009

2625 Yao Li, Borders and Distance in Knowledge Spillovers: Dying over Time or Dying with Age? - Evidence from Patent Citations, April 2009

2626 Jim Malley and Ulrich Woitek, Technology Shocks and Aggregate Fluctuations in an Estimated Hybrid RBC Model, April 2009

2627 Jin Cao and Gerhard Illing, Endogenous Systemic Liquidity Risk, April 2009

2628 Thiess Buettner and Bjoern Kauder, Revenue Forecasting Practices: Differences across Countries and Consequences for Forecasting Performance, April 2009

2629 Håkan Selin, The Rise in Female Employment and the Role of Tax Incentives - An Empirical Analysis of the Swedish Individual Tax Reform of 1971, April 2009

2630 Nick Johnstone and Ivan Hascic, Environmental Policy Design and the Fragmentation of International Markets for Innovation, April 2009 